part of the national security structures it may part with the sole control of this weapon. As long as the occupation of Palestinian territory persists, only "nationalized" rocket arsenals can be negotiated away. Of course, there is no guarantee for this policy to succeed. But since the opposite policy has backfired, it is worth trying. In the run-up to the elections in Lebanon, a number of European governments signalled support of a future Lebanese government that would include Hezbollah, hoping that its pro- motion from an opposition party to a governing party would eventually result in the Shia movement putting its formidable paramilitaries under the control of the regular Lebanese armed forces. This turnabout, viewing the Lebanese resistance movement as a potentially constructive force in Lebanese politics, could signify that a policy change vis à vis the Palestinian $\mathrm{Ha}$ mas is also in the making.

\title{
Zimbabwe still at the Crossroads?
}

\section{Domestic Stalemate, Regional Appeasement, and International Half-Heartedness}

\author{
Martin Welz*, Julian Junk
}

\begin{abstract}
This article examines the larger political picture of Zimbabwe, focusing on last year's developments at the domestic, regional and international level. It finds that Zimbabwe is on a downward spiral of domestic stalemate, regional appeasement and international half-heartedness, and that there is need for a coherent strategic effort to replace this triad with domestic change, regional active engagement and international steady commitment. Otherwise, both Zimbabwe and the region risk long-term instability with devastating national and regional consequences. In the end, the article outlines and assesses various scenarios for the future development of Zimbabwe, of which the most likely is status quo conservation.
\end{abstract}

Keywords: Zimbabwe, South Africa, SADC, African Union, United Nations

Simbabwe, Südafrika, SADC, Afrikanische Union, Vereinte Nationen

\section{Introduction}

$\mathrm{T}$ The political and economic situation in Zimbabwe attracts extensive international attention when elections are held, farmland is seized or the hyperinflation reaches yet another peak. Media coverage was particularly high in the last 14 months. In this period, elections were held in March and June 2008, followed by a negotiated settlement of the dispute between the ruling and opposition party which ultimately led to the formation of a 'Unity Government' in February 2009. It was argued that Zimbabwe reached an important point in its post-colonial history when Mugabe seemed willing to share power after almost 30 years in office. In fact, Zimbabwe appeared to be at the crossroads in February 2009. ${ }^{1}$ However, looking closer at the political landscape in Zimbabwe, the conclusion seems rather that the status quo is prevailing for the time being and that the crossroad might still be ahead.

This article sheds light on the larger political picture of Zimbabwe by focusing on last year's developments on the domestic, regional and international level and by including very recent events like the election in South Africa into the analysis. The

\footnotetext{
* Martin Welz is Research Fellow at the University of Konstanz, Germany (martin.welz@uni-konstanz.de). Julian Junk is Research Fellow at the University of Konstanz, Germany, and Visiting Fellow at the International Peace Research Institute (IFSH) in Hamburg, Germany (julian.junk@uni-konstanz.de). The authors are grateful for the valuable recommendations of the two anonymous reviewers and for the financial support of the Center of Excellence "Cultural Foundations of Integration" and the Collaborative Research Center (SFB) 485 "Norm and Symbol" for providing amongst others funds for extensive field research in various African countries and for supporting our research team. This article is peer-reviewed (double-blind).

1 See, for instance: The World, 18 April 2009, "Zimbabwe at the crossroads", http://www.theworld.org/node/8849 (accessed 03 May 2009).
}

study is based on both extensive field research in Zimbabwe, South Africa and Ethiopia ${ }^{2}$ as well as a review of literature, government documents and newspaper reports.

On the international level, we find that there is an urgent need for the 'international community' not to lose sight of Zimbabwe while other crises appear to gain more volatile attention. Moreover, there is a need to match rhetoric (though it is a very important political tool) more frequently with delivered action. However important the broad international pressure on Zimbabwe might be, the key to the solution seems to lie on the regional level, particularly on the two pivotal and intertwined players South Africa and the Southern African Development Community (SADC). The new South African President Jacob Zuma has not positioned himself publicly on the issue of Zimbabwe, but he seems to be willing to engage regionally. On the domestic level, the political stalemate between the 'partners' of the Unity Government needs to be resolved. It appears to be

2 Interviews in Addis Ababa, Ethiopia, were conducted in October and November 2008. Interviewees include AU Commissioners, AU officials, several Ambassadors to the African Union, academics and think tanks. In February 2009, interviews were conducted in Harare, Zimbabwe. Various political actors like high rank officials from the MDC-Tsvangirai, MDC-Mutambara, allies of Simba Makoni, influential figures in ZANU-PF, high representatives from western Embassies and the Zimbabwe Congress of Trade Unions and a number of persons from important lobby groups like the Commercial Farmer's Union and Justice for Agriculture as well as academics were interviewed. Moreover, a former Press Secretary of President Mugabe provided interesting insights into Mugabe's governing style. Additionally, in March and April 2009 a number of interviews were conducted in Midrand and Pretoria, South Africa, at the NEPAD Secretariat as well as with members of the Pan-African Parliament election observer mission to Zimbabwe. Moreover, high rank members of the South African diplomatic corps provided insights into the topic. As many of the interviewees asked for anonymity, we will only occasionally make explicit references to names and positions 
a government of a frozen two- or even three-party conflict. It seems that change needs to be induced from the outside.

While the current situation can be summarized as being on a downward spiral of domestic stalemate, regional appeasement and international half-heartedness, there is a need for a coherent strategic effort to replace the aforementioned triad with domestic change, regional active engagement and international commitment. Otherwise, the future of both Zimbabwe and the region future teeters at the brink of instability with devastating consequences for the country and even the continent as a whole.

The article moves in the following order: firstly, on the domestic level, the political situation since the elections of March 2008 is described and analyzed. Secondly, an analysis of the regional level follows with a closer look at SADC's negotiation efforts, which are closely linked with, thirdly, South Africa's 'quiet diplomacy'. Fourthly, both the actions and the reluctance of the international community are approached, including a media analysis about the newspaper coverage of the political situation of Zimbabwe. The article ends by outlining and assessing various scenarios for the future development of Zimbabwe.

\section{Current political situation in Zimbabwe: the 2008 election aftermath}

The 2008 parliamentary and presidential elections in Zimbabwe were overshadowed by a high level of political violence. ${ }^{3}$ Experiences from the 2005 election and the following brutal and thoroughly planned operation "Murambatsvina" 4 , through which opposition voters were persecuted, raised concern whether a free and fair election in 2008 was possible. Indeed, campaigning, voting and counting followed a well-known pattern: firstly, the opposition could not campaign freely; secondly, ghost voters voted for the ruling Zimbabwe African National Union - Patriotic Front (ZANU-PF); thirdly, violent campaigns against the voters of the opposition were started to keep them away from the polls; and lastly, the counting of the votes was rigged. ${ }^{5}$

In this light, the official results of the elections came to a certain extent as surprise: The main opposition party, the Movement for Democratic Change (MDC) won the majority of the seats in the parliament, and its presidential candidate Morgan Tsvangirai got more votes than Mugabe in the race for the presidency. The MDC could claim its victory based on the results published at each polling station. SADC and its mediator, South Africa's then President Thabo Mbeki, had forced the Mugabe regime to publish the results directly at each polling station after the counting of the votes. The MDC used these published results, added them up and consequently claimed to have won both the majority of the seats in parliament and the presidency for Tsvangirai before the official results were released. This left little space for ZANU-PF maneuvers. The way the ZANU-PF regime

3 Africa Research Bulletin, Vol. 45 No. 4, April 1st - 30th 2008, p. 17484 A, B.

4 Another official name was "restore order", literally, "Murambatsvina" means, however, "drive out trash". See for more details on both the operation itself and the thoroughly planning of it: Kamete, Amin Y. (2009): In the Service of Tyranny: Debating the Role of Planning in Zimbabwe's Urban, Clean-Up“ Operation, in: Urban Studies, 46 (4), pp. 897-922.

5 Frankfurter Rundschau, 29 March 2008, "Meister der Wahlfälschung“, p.10. saw to get out of this situation was to count the votes in a way so it appeared that Tsvangirai had indeed won more votes than Mugabe but failed to win the out-right majority and, hence, a second round of elections was necessary. With regard to the parliamentary election, ZANU-PF admitted to have lost.

What happened behind closed doors when high-rank ZANUPF officials gathered under the banner of the Joint Operational Command (JOC) ${ }^{6}$ to discuss the matter is not exactly known. There is, however, no doubt among observers and politicians in Zimbabwe that Mugabe wanted to resign at this stage. ${ }^{7}$ There are a couple of thoughts supporting the argument: Firstly, Mugabe seemed to have finally realized that support for his movement was diminishing in the population. Mugabe originally intended to stay in office until he dies, yet, facing defeat, he considered his dignity more important. Heidi Holland's seminal work on Mugabe sheds some light on this characteristic of him. ${ }^{8}$ Secondly, there was rumor that Mugabe might be given a golden parachute, namely amnesty. ${ }^{9}$ Yet, there was never a discussion that a general amnesty would be granted, meaning that high rank ZANU-PF officials were not secure. The latter played a crucial role in the human rights violations during the past 29 years since Zimbabwe's independence, most notably the ethnic cleansing in Matabeleland in the 1980s. Hence, the ruling clique needed Mugabe to stay in power so that they remain safe without fearing prosecution. They felt insecure about their future, since a general amnesty was not explicitly discussed at this stage, as many interviewees confirmed. Moreover, the JOC members preferred keeping the status quo, namely having political and economic influence. Ibbo Mandaza expresses this phenomenon by saying "today I am a minister, tomorrow I starve." ${ }^{10}$ Certain JOC-members loudly claimed that they would never salute to a president Tsvangirai. ${ }^{11}$ They need Mugabe and Mugabe needs them. The President was quite aware that he would run into serious trouble if he surrendered without ensuring the security and survival of the ruling clique. They would find a way to hold him responsible for his command, particularly with regard to the above-mentioned Matabeleland incident and operation "Murambatsvina" in 2005. In the end, as a collective body, they saw no other way than to manipulate the vote count of the first round of the presidential election to create space for tactical maneuvers. This strategy worked out in the end. The run-off election was postponed for several weeks, although the electoral laws explicitly demanded

6 The JOC is comprised of the heads of the army, the air force, intelligence, national police and prison service. Under the new Government of National Unity, the JOC has been formally expanded by a seat for the prime minister and is called National Security Council. It has not convened so far. Harare Tribune, 27 May 2009, "Scott A. Morgan: The Two Factors that will Determine Zimbabwe's Future".

7 Mail and Guardian online, 4 April 2008.

8 Holland, Heidi (2008): Dinner with Mugabe: The Untold Story of a Freedom Fighter Who Became a Tyrant Penguin, New York. See as well: Meredith, Martin (2007): Mugabe: Power, Plunder, and the Struggle for Zimbabwe's Future. Public Affairs, New York. or Alexander, Jocelyn (2006): The Unsettled Land: State-Making and the Politics of Land in Zimbabwe, 1893-2003. Ohio University Press, Athens, $\mathrm{OH}$

9 Mail and Guardian online, 4 April 2008

10 Interview with Ibbo Mandaza, Harare, 23 February 2009. Ibbo Mandaza is currently Head of the Southern Africa Political and Economic Series (SAPES) Trust based in Harare. He obtained many different positions before and was even seen as close to Mugabe at a certain point in time. Also see Chan, Stephen (2003): Robert Mugabe: A Life of Power and Violence, The University of Michigan Press, Ann Arbor, pp. 114-115.

11 The Financial Gazette, Harare 19-25 February 2009, p. 1. 
it to be held within three weeks after the first round. ${ }^{12}$ That gave ZANU-PF more time to prepare the manipulation of the elections, increase pressure on opposition voters and start brutal campaigns and massive intimidation, particularly in areas of the MDC strongholds. Tsvangirai withdrew from the election race according to the MDC due the massive politically motivated violence, leaving Mugabe as the only candidate left. ${ }^{13}$ It remains unclear whether Tsvangirai's decision was part of ZANU-PF's calculation. The ruling clique was certainly pleased, as the democratic façade could be kept up during the second round of the presidential election. ${ }^{14}$ After being elected and hurriedly sworn-in at the Zimbabwe State House complex on 29 June 2008, Mugabe rushed to the African Union summit taking place in Sharm El-Sheikh on 30 June and 1 July 2008 to gain legitimacy from Africa's leadership, which was widely granted to him even if there were numerous objections (see section 3 ).

Months of hard negotiations followed. On 15 September, the MDC and ZANU-PF agreed on a power-sharing arrangement. The agreement was certainly inspired by the 'Kenyan-solution' which solved Kenya's political stalemate after the elections of December 2007. SADC and South Africa's President Mbeki who mainly facilitated the deal expressed pride since they considered themselves able to find an 'African solution for an African problem' - a recurring discursive theme throughout the negotiations. It took, however, until the beginning of 2009, almost one year after the first round of election and more than four months after the power- sharing agreement, for the new government to be sworn in with Mugabe as President holding executive power and Tsvangirai in the position as Prime Minister also vesting executive power. Mugabe managed to secure the same amount of minister posts for his party and to remain in control of all important security organs. The MDC received the Ministry of Finance (Tendai Biti), yet, Mugabe made sure that one of his closest allies and likely successor, Gideon Gono ${ }^{15}$, remained the Governor of the Reserve Bank. In this position Gono can control Biti. It took less than two weeks until the two started to fight about competences. Biti described "Gono as an 'Al-Qaeda'-like official deserving to be put before a firing squad for his activities as central bank governor." ${ }^{16}$ Gono is seen as the architect of Zimbabwe's disastrous economic situation.

Despite the power-sharing agreement, Mugabe and his cronies will remain strong in power, as the following three points un-

12 Electoral Act, Section 101, http://aceproject.org/ero-en/regions/africa/ZW/ Zimbabwe\%20-\%20ElectoralAct.pdf (accessed 02 May 2009).

13 The Economist, 26 June 2008 , "An Election With Only One Candidate".

14 This pattern occurred regularly: as Kriger shows, Mugabe used the rhetoric of democratic reform already quite extensively in 2005 to conceal his hegemonic ambitions. Kriger, Norma (2008): Zimbabwe‘s Parliamentary Election of 2005: the Myth of New Electoral Laws, in: Journal of Southern African Studies, 34 (2), pp. 359-378.

15 Gideon Gono and Emmerson Mnangagwa are said to be the two most likely successors of President Mugabe in late 2008 and early 2009. This was different in late 2007, when a list of possible successors was leaked after Mugabe spoke with Mbeki. At that time, Gono was not even on the list. Due to Mnangagwa's involvement in the Tsholotsho incidence (see section 6) there are many sources in Harare who assume that Gono is Mugabe's choice currently. His reappointment as Reserve Bank Governor in December against the MDC's position is an indication for the confidence Mugabe has in Gono. However, it must be emphasized that the successor question is not solved yet. ZANU-PF is build around Mugabe who is currently still in the driver's seat. For Gono and Mnangagwa as successors of Mugabe see The Times online, 29 June 2008. http://www.timesonline.co.uk/tol/news/world/africa/article4232169.ece

16 The Zimbabwe Independent, Harare, 20 -26 February 2009, "Biti, Gono war escalates", p. 1. derline: Firstly, Gono can play a key role in sabotaging the new government, as he controls all remaining financial resources the country has. He has lost some influence as the currencies used in Zimbabwe are now the US-Dollar, South African Rand and Botswana's Pula (due to hyperinflation of the Zimbabwean dollar), yet, he still controls the country financially from the impressive multi-store Reserve Bank building in downtown Harare. Secondly, the ZANU-PF organized police force did not even shy away to detain Roy Bennett, delaying his inauguration as Deputy Minister for Agriculture for weeks and creating the first test case for the Prime Minster. ${ }^{17}$ Lastly, rhetoric also tells a story. As a European diplomat remarked in an interview, Zimbabwe's President does not use the phrase "Unity Government" as Tsvangirai does, but "Inclusive Government".

Particularly the detention of Roy Bennett brought up the question of who advises Tsvangirai. Roy Bennett, a dispossessed white farmer who was in South African exile, was named as Deputy Minister of Agriculture by the MDC. When Bennett returned from South Africa, he was detained. This questioned the power-sharing agreement and it was asked why the MDC did not withdraw from government. The event overshadowed the creation of the unity government and was considered as a false start for the new government. ${ }^{18}$ What seems to be sure is that Mugabe is not completely misguided when he suggests that Tsvangirai is massively influenced by the British government. ${ }^{19}$ The British and the US-American embassies in Harare seem to play a crucial role in advising the MDC leader. There are clear signs that the Americans were furious when Tsvangirai decided to join the Unity Government. ${ }^{20}$ Behind the scenes they opposed a power-sharing agreement between ZANU-PF and MDC. The European position in this context is not quite clear and not as united as it seems at the surface. The interviewees confirmed that many Europeans countries, including Britain, were largely doubtful about the power-sharing agreement. Now they have to cope with the situation and adapt their strategies in the turbulent waters of Zimbabwe's policy. Although one needs to be cautious when non-Africans judge African politics in simple categories, the expressed view of one diplomat that Tsvangirai and the new government have simply "no clue" how to run a country is not completely out of touch with the real world..$^{21}$ So far, only Tendai Biti, the country's new Minister of Finance (MDC), emerged with credit from this bumpy start of the new government. He was "the chief negotiator of the power-shar-

17 The New York Times, 14 February 2009, "Zimbabwe Opposition Party Official Arrested“; The Guardian, 17 February 2009, "Zimbabwe Court Charges MDC Politician Over Alleged Terrorism Plot“.

18 The Financial Gazette, Harare, 17-25 February 2009, p. 4.

19 Mugabe uses the word 'puppet'. See e.g. Daily Mail online, 7 April 2008, http://www.dailymail.co.uk/news/article-557877/Help-Britain-urges-Tsvangrirai-international-effort-oust-Mugabe.html (accessed 28 March 2009). See as well: The New York Times, 3 January 2009, "Mugabe Preparing to Install New Cabinet in Zimbabwe".

20 Interviews with western diplomats, Harare, February 2009.

21 The political situation in Zimbabwe is far more complex than it already appears. There are many different influential players in the political arena, which are often neglected when drawing a picture of the political developments of Zimbabwe. Among these are Simba Makoni who ran as independent candidate, Athur Mutambara, the Commercial Farmer's Union, Justice for Agriculture, and, generally, the trade unions. A closer analysis of the players is, however, beyond the scope of this article and subject to forthcoming work. (Martin Welz 2010, “The Round Table”, special issue on Zimbabwe). 
ing deal with ZANU-PF, [and] he has proven himself an able politician."22

\section{The role of the AU and the SADC}

The role the African Union (AU) played in the month following the first and second round of the elections in 2008 was minor. There was no extraordinary summit held. The AU passed the issue to SADC. However, the AU - not intentionally but by accident - played an important role in Mugabe's political game. As described above, Tsvangirai had left the race leaving Mugabe as the only candidate in the run-off. The results were released within a matter of hours after the polling, whereas it took several weeks to release the results of the first round. Mugabe managed to be sworn in immediately and rushed the day after to the AU summit taking place in Sharm El-Sheikh in June 2008. As the Zimbabwean Herald quotes Mugabe before leaving to Egypt:

"some African countries have done worse things and when I [Mugabe] go to the AU meeting, I am going to challenge some leaders. [...] I would like some leaders who are making these statements [questioning whether the second round of the presidential election in 2008 was democratically] to point at me and we would see if those fingers would be cleaner than mine."23

Having spoken to participants of the closed session at the AU summit, it is clear that Mugabe followed through with what he had announced publicly beforehand and silenced all critical voices. He was heavily criticized for his undemocratic behavior by some heads of state, most vocally by Zambia's President Levy Mwanawasa who suffered from a stroke at this stage and died soon thereafter. In reaction to his critics, Mugabe emphasized the shortcomings in terms of good governance in their own countries and reinforced his words by pointing a finger at other non-democratically elected leaders. What he essentially did was to use the AU for something the AU's predecessor organization, the Organization of African Unity (OAU), was famous for, namely being a platform to gain legitimacy from outside. In fact, the OAU was often referred to as "club of dictators", "toothless talking shop" or "toothless bulldog". ${ }^{24}$ A case in point is the statement by Jean Ping, the Chairman of the Commission of the AU, at a meeting of the AU's foreign ministers in June 2008. While he was summarizing the current problems of the African continent, he shied away from mentioning Zimbabwe and stated only vaguely: "We will engage in a deep reflection on the general problem of elections on this continent", and the Egyptian foreign minister added that "Egypt will not prejudge the results of the elections or the results of deliberations". 25

22 BBC News, 10 February 2009. http://news.bbc.co.uk/2/hi/africa/7881582. stm.

23 The Herald, 27 June 2008, p. 1.

24 See e.g. Biswaro, Joram Mukama (2005): Perspectives on Africa's Integration and Cooperation from OAU to AU: "Old Wine in a new Bottle", Dar es Salaam: Tanzania Publishing House Limited.

25 The Guardian, 28 June 2008, "Zimbabwe election: G8 refuse to accept vote as African Union leaders fail to agree common stance: What they said“, p.7 .
Despite Mugabe's massive pressure, the gathered heads of state concluded that they needed to issue a statement urging for a dialogue between ZANU-PF and MDC. They urged

"to encourage President Robert Mugabe and the leader of the MDC Party Mr. Morgan Tsvangirai to honour their commitments to initiate dialogue with a view to promoting peace, stability, democracy and reconciliation of the Zimbabwean people; to support the call for the creation of a Government of National Unity [and] to support the SADC facilitation, and recommend that SADC mediation efforts should be continued in order to assist the people and leadership of Zimbabwe to resolve the problems they are facing. In this regard SADC should establish a mechanism on the ground in order to seize the momentum for a negotiated solution". ${ }^{26}$

Contrary to the AU, the SADC was heavily involved. It played a pivotal role in the phase preceding the elections of March 2008. Immense pressure from SADC countries made it possible for the MDC and other opposition parties to campaign relatively freely. Repressive media and security laws were eased, for instance, in December 2008. ${ }^{27}$

The SADC, however, turned a blind eye to the undemocratic conditions during the polling process. ${ }^{28}$ In their words: "These elections were characterized by high levels of peace, tolerance and political vigor of party leaders, candidates and their supporters. [...] With regard to the polling process, it is SADC's overall view that the elections were conducted in an open and transparent manner." 29

At an extraordinary meeting of the SADC Troika, the regional bloc's organ on politics, defence and security, ${ }^{30}$ on 25 June 2008, shortly before the run-off election, were not condemning the ongoing political violence in Zimbabwe but made a recommendation to postpone the election. They held the view that

"in the light of the violence and the charged political atmosphere, the political and security situation in Zimbabwe appears not to be permissive for holding the run-off election in a manner that would be deemed free and fair. It is the considered opinion of the Organ Summit that holding the elections under the current circumstances may undermine the credibility and legitimacy of its outcome. [...] The Organ Troika Summit believes that the people of Zimbabwe are capable of charting their country's future in peace and harmony."31

The tone of the SADC observer mission of the run-off election became harsher. The mission was of "the view that the prevailing environment impinged on the credibility of the electoral process. The elections did not represent the will of the people of

26 Assembly/AU/ Res.1 (XI).

27 Africa Research Bulletin Vol. 45 No. 1, 01 January - 31 January 2008, p: 17385 C.

28 Africa Research Bulletin, Vol. 45 No. 3, 01 March - 31 March 2008, page: 17449 B.

29 SADC Observer Mission: Preliminary Statement 30 March 2008 http://www. eisa.org.za/PDF/zim2008sadc.pdf (accessed 02 May 2009).

30 The troika was started as an ambitious nucleus of a further integration of SADC member states on matters of security policy. See for more details Ngoma, Naison (2003): SADC: Towards a Security Community, in: African Security Review 12(3), pp. 17-28.

31 http://www.sadc.int/attachments/news/Organ\%20Troika\%20Summit\%20C ommunique\%20\%2025\%20Junel\%202008\%20English.pdf (accessed 02 May 2009). 
Zimbabwe."32 Apart from SADC, Zimbabwe's government had also invited the Pan-African Parliament to observe the run-off election. Their conclusion was similarly "that the atmosphere prevailing in the country, at the time, did not give rise to the conduct of free, fair and credible elections". ${ }^{33}$ It is noteworthy that the websites of Zimbabwe's government only show the positive statements of the first round of election. ${ }^{34}$

Although SADC members with the exception of Botswana and Zambia $^{35}$ have not publicly criticized Mugabe, they continued to pressure the regime behind closed doors. Most importantly in this regard was South Africa's President Mbeki who was appointed as mediator. SADC and Mbeki were searching for a negotiated settlement, inspired by the idea of powersharing between the MDC and ZANU-PF. The debate took place at the highest political level. The embassies were only involved at the margins. Crucial for the achievement of the political settlement was Mbeki himself and a small circle of people engaged in the shuttle diplomacy, as we will elaborate on in the following.

\section{South Africa's quiet diplomacy in Zimbabwe}

Undoubtedly, South Africa played a crucial role in the Zimbabwe conflict. Expectations and pressure from the international community and from within the domestic audience on Presidents Mbeki and Mothlante were high. ${ }^{36}$ Yet, South Africans rarely appeared openly at the stage engaging in a public debate on Zimbabwe. ${ }^{37}$ More openly discussed occasions were President Mbeki's effort to engage Tsvangirai and Mugabe in direct talks in August 2008 to facilitate negotiations ${ }^{38}$ and in midJanuary 2009 after negotiations for a political settlement had stalled. Mbeki dispatched Sydney Mufamadi, his top dialogue facilitator, to Harare in a bid to revive the negotiation process. ${ }^{39}$ But most of the time South Africa's efforts were behind closed doors. This short section sheds some light on the motives for South Africa's ‘quiet-diplomacy’ approach.

South Africa's position toward Zimbabwe is inspired, as we shall elaborate below, firstly by the bond the ANC and ZANU forged during South Africa's liberation struggle, secondly by the consequences of 'Mugabe's revenge' for South Africa's 'un-African' behavior and criticism toward himself, thirdly by a perceived threat of a massive influx of Zimbabwean citizens into South Africa in the event of a civil war, and, lastly, by possible spill-

32 http://www.sadcpf.org/SADC\%20EOM\%20prleliminary\%20statement\%20 29\%20June\%202008.pdf (accessed 02 May 2009).

33 http://www.pan-africanparliament.org/DocumentsResources_DisplayDocument.aspx?Type $=$ Docs\&ID=1029 (accessed 02 May 2009).

34 http://www.zimfa.gov.zw/current/observers.htm (accessed 02 May 2009).

35 Guardian Online, 2 July 2008, http://www.guardian.co.uk/world/2008/ jul/02/zimbabwe (accessed 02 May 2009).

36 The Washinghton Post, 30 April 2008, p. 18.

37 For an overview on South Africa's engagement in Zimbabwe see Gumede, William Mervin (2005): Thabo Mbeki and the Battle for the Soul of the ANC. Zebra Press: Cape Town. p. 175-194.

38 The Guardian, 11 August 2008, p.15.

39 Mbeki's efforts failed after a police raid on Tsvangirai, who was seized from his home on 23 January as the MDC prepared protests against Mugabe in defiance of a police ban. See: Africa News, 24 January 2008, "Tsvangirai Arrested in Dawn Raid"; Mail \& Guardian, 25 January 2008, "Zimbabwe mediation said dealt blow by opposition leader's arrest, protests purge”. The break with the focus on non-public diplomacy might, however, be triggered not only by a window of opportunity that the rise of Tsvangirai opened but by the overwhelming topic in the South African media at that time: violence in townships and refugee camps with the involvement of African migrants most notably Zimbabwean refugees. over effects of a violent conflict into South Africa. Taken together, all these different aspects explain South Africa's 'quiet diplomacy' towards Zimbabwe. ${ }^{40}$

After Ian Smith's South Rhodesia was transformed into the independent Zimbabwe by the Lancaster House Agreement of 1979 , the last piece of the belt of white-ruled states surrounding and protecting Apartheid South Africa disappeared. The new black Zimbabwean regime openly supported the liberation movement in South Africa. Mugabe became "leader of the 'Front-line states' in the fight against Apartheid". ${ }^{41}$ Mandela made it clear in a speech by stating:

"we do thank you from the bottom of our hearts, knowing the cost inflicted upon you by the apartheid regime because you supported us. Despite the cost to yourselves, you gave us material and moral support; a home from home for our exiles; and a voice in the councils of the region, the continent and the world. [...] We reaffirm our pledge, that never again will South Africa be a source of violence and destabilization against Zimbabwe." 42

Indeed, Zimbabwe has benefited from the African National Congress (ANC)-government since the end of Apartheid. Since the ANC under Mandela took power, the foreign policy of South Africa had a strong component of regional engagement as Mandela put it in his famous article in Foreign Affairs: South Africa has an "African destiny". ${ }^{43}$ This policy approach is not specific to Zimbabwe, in fact, all states having supported the ANC during its liberation fight benefit from the loyalty of the ANC-government, as can be seen e.g. with regard to Swaziland, where ANC cadres were stationed to launch the guerilla fight. ${ }^{44}$ Facing the difficulties in the last years, however, it seems notable that South Africa publicly announced a security cooperation with Zimbabwe: Ronnie Kasrils, the then security minister of South Africa even said that under this security cooperation the two countries will "march shoulder to shoulder", invoking thereby this strong historical bond of the common fight. ${ }^{45}$

Despite this seemingly good relationship between the two parties, there was a personal rivalry between Mugabe and Mandela. Mugabe was the hero of the liberation fight ${ }^{46}$, gaining a lot of respect from other African states during the 1980s. "He [Mugabe] was the star and then the sun [Mandela] came up". ${ }^{47}$ "Mugabe disliked Mandela for upstaging him as elder statesman of Africa, and Madiba's [Mandela's] global fame and acclamation were hard for Mugabe to respect. ${ }^{48}$ In short, Mugabe's vanity

40 Some claim that Mbeki's policy was rather a diplomatic fig leaf used to cover „business as usual“ towards the Mugabe regime. See, for instance, Davies, Joanne E. (2008): South Africa and Constructive Engagement: Lessons Learned?, in: Journal of Southern African Studies, 34 (1), pp. 5-19.

41 Russell, Alec (2000): Big Man, Little People: the Leaders Who Defined Africa. New York University Press, New York, p. 306.

42 Mandela, Nelson, 20 May 1997, http://www.queensu.ca/samp/sampresources/migrationdocuments/ speeches/speech2.htm (accessed 02 May 2009).

43 Mandela, Nelson (1993): South Africa‘s Future Foreign Policy, in: Foreign Affairs, 72 (5), pp. 86-97. See chapter on „African Destiny“, pp. 89-93.

44 Interview with Petros Magagula, Department of Political Science at the University of Swaziland. Manzini, 15 April 2009; Robbins, David (1982): The South African Land Deal in Africa Report 6, pp. 18-22.

45 Dowden, Richard (2006): Engaging with Mugabe, in: The Round Table, Vol. 95 (384), 283-286, p. 284.

46 Meredith, Martin (2005): The State of Africa. A History of Fifty Years of Independence. London: Free Press.

47 Sparks, Allister (2003): Beyond the Miracle: Inside the new South Africa. University of Chicago Press, Chicago, p. 269.

48 Gumede, William Mervin (2005): Thabo Mbeki and the Battle for the Soul of the ANC. Zebra Press: Cape Town. p. 186. 
was attacked when the world focused on Mandela and his rainbow nation and forgot about him. Mugabe's personal problems with Mandela and later Mbeki became apparent through two events. Firstly, when the Congo Crisis erupted in 1997, Mugabe as chair of the SADC Organ on Politics, Defence and Security, convened a conference on the Congo issue explicitly not inviting South Africa's President Mandela. ${ }^{49}$ Secondly, he subverted South Africa's most important foreign policy desire, namely a permanent seat in the UN Security Council. South Africa's increasing pressure on the African states to grant the country a seat in a reformed council as discussed in mid-2005 happened at the same time when Mbeki started to increase pressure to Mugabe and his ZANU-PF regime at the advent of the 2005 elections. Observers say that Mugabe took revenge at an AU meeting when the gathered leaders discussed their position to the proposal of including two African states alongside Brazil, India, Germany and Japan in the extended Security Council. He "shor[ed] up opposition to South Africa's desire to what they wanted probably most", as an insider stated in an interview. Ultimately, the reform plans failed. Mbeki learned that he had to choose his words more carefully when approaching Mugabe and became even more committed to the 'quiet diplomacy'. ${ }^{50}$ "Mugabe [...] holds a dim view of Mbeki, whom he regards as an arrogant young upstart who should defer him as an elder statesman." 51 In fact, the relationship between Mbeki and Mugabe was not easy. Drawing lessons from past events, Mbeki believed in a "non-confrontational stance towards Mugabe" 52 as the best approach. This went so far that he made a statement that there was "no crisis" 53 in Zimbabwe in the immediate aftermath of the March 2008 election. As Gevisser points out in his biography of Mbeki, this behavior is rooted in general characteristics of Mbeki as a politician: he appears to be a man of the status quo, a back room negotiator, and a supporter of Western non-intervention in African affairs. ${ }^{54}$ It appears that Mbeki was successful in gaining Mugabe's trust. ${ }^{55}$ They appeared holding each others' hands in front of the international press on 12 April 2008 - a particular forceful image as it was widely covered internationally right before the SADC meeting in Zambia and a high-level UN Security Council on 16 April 2008. ${ }^{56}$

South Africa's government pursues the events in Zimbabwe very closely. It knows that an imploding Zimbabwe has at least one negative impact on South Africa: namely a massive increase in the influx of refugees. Already shortly after the election in July 2008, 138,000 Zimbabweans were officially registered as refugees in South Africa ${ }^{57}$, but the estimates (in particular, if

49 Barber, James (2004): Mandela's World: the International Dimension of South Africa's Political Revolution, 1990-1999. James Curry, Oxford, pp. 192-195.

50 See Gumede, William Mervin (2005): Thabo Mbeki and the Battle for the Soul of the ANC. Zebra Press: Cape Town. p. 178-179.

51 Ibid, p. 186

52 Africa Research Bulletin, Vol. 45 No. 4, April 1st-30th, 17485 B.

53 BBC News, 12 April 2008, http://news.bbc.co.uk/2/hi/africa/7343907.stm.

54 Gevisser, Mark (2008): Thabo Mbeki: the Dream Deferred. Jonathan Ball Publishers, Jeppestown. (updated international edition)

55 Ibid, p. 304.

56 Sidney Morning Herald, 13 June April 2008, „Crisis? What crisis, says Mbeki on way to summit“; BBC News, 17 April 2008, „Mbeki defends record on Zimbabwe“ (http://news.bbc.co.uk/2/hi/africa/7351755.stm).

57 UNHCR - http://www.unhcr.de/aktuell/einzelansicht/browse/9/article/5/tausende-simbabwer-suchen-asyl-in-suedafrika.html?PHPSESSID=bceb394423c a358ff3de1130740ca69b (July 2008). unregistered refugees are included) are much higher. ${ }^{58}$ In addition, cholera is spreading not only in Zimbabwe ${ }^{59}$ but across the border to South Africa. ${ }^{60}$ This in turn might lead to social tensions in South Africa. Already in 2005, Billy Masetla, South Africa's security intelligence chief, did express "huge concern" about the numbers of Zimbabweans fleeing across the South African border. ${ }^{61}$ As the xenophobic attacks of 2008 show, there are a lot of social problems and tensions in South Africa which can easily cause turmoil and - fuelled by spill-over effects from a civil war in Zimbabwe - also cause a serious threat to South Africa's internal security.

It is too early to judge on South Africa's new President Zuma and his position toward Zimbabwe. But some noteworthy patterns can be identified from his past and translated into assumptions. Zuma appears to be a pragmatist and not an ideologue. ${ }^{62}$ Zuma is by no means a newcomer to regional politics. He was involved in South Africa's quiet diplomacy in the past. It was mainly him who facilitated the peace process in Burundi at the beginning of the decade. ${ }^{63}$ Zuma might concentrate on South Africa's domestic challenges and not engage in the foreign policy arena - the economic developments in the current global recession might leave him with no other choice. While Zuma has and Mandela had their priorities on domestic politics, Mbeki had left the South African arena and engaged extensively in continental affairs. As Gumede put it, he wanted to escape Mandela's big footsteps and saw a way in engaging in what he called the African Renaissance. ${ }^{64}$ The latter is an ambitious project, which found its expression in the continental development program New Partnership for Africa's Development (NEPAD) and the AU. Zuma is more likely to go back to the ANC's domestic roots. Mbeki's elitist policy approach which stands in contrast to Zuma's strong preference for the grassroots level of society certainly fuelled the decision to replace Mbeki as ANC President at the well known ANC National Conference in Polokwane 16-20 December 2007. ${ }^{65}$ This meeting must be seen as the beginning of Mbeki's political end. For the situation in Zimbabwe, Zuma's election might mean that South Africa will not play the influential role it has played in the past few months. In his first state of nation address on 3 June 2009 Zuma focused almost completely on domestic matters. ${ }^{66}$

58 Médecins Sans Frontières (MSF), for instance, counts 3 million Zimbabwean in South Africa most of which are termed officially as „economic voluntary migrants" - www.aerzte-ohne-grenzen.at/img/db/msfmedia-6395.pdf (February 2009).

59 Ibid. - MSF estimates roughly 60.000 cases.

60 Frankfurter Allgemeine Zeitung, 11 December 2008, „Die Cholera greift von Zimbabwe auf Südafrika über“.

61 Dowden, Richard (2006): Engaging with Mugabe, in: The Round Table, Vol. 95 (384), 283-286, p. 284.

62 The Times London, 24 April 2009, "A Question of Competence Not Conscience", p. 26

63 See e.g. http://www.info.gov.za/speeches/2002/02092709461003.htm

64 Gumede, William Mervin (2005): Thabo Mbeki and the Battle for the Soul of the ANC. Zebra Press, Cape Town, pp. 201.

65 The Independent (London), 29 December 2008, p. 32.

66 He rather seems to continue with the South African policy of the last years. He was mentioning Zimbabwe once: „As the Chairperson of SADC and Facilitator, we will participate in promoting inclusive government until free and fair elections are held in Zimbabwe. The plight of the Zimbabwean people has had a negative impact on the SADC region, especially South Africa. We call upon all peace-loving countries in the world to support the inclusive government to achieve economic recovery."

(http://www.info.gov.za/speeches/2009/09060310551001.htm - 03 June 2009). 
Figure 1: Frequency of international media reporting on Zimbabwe - January 2006-April 2009*

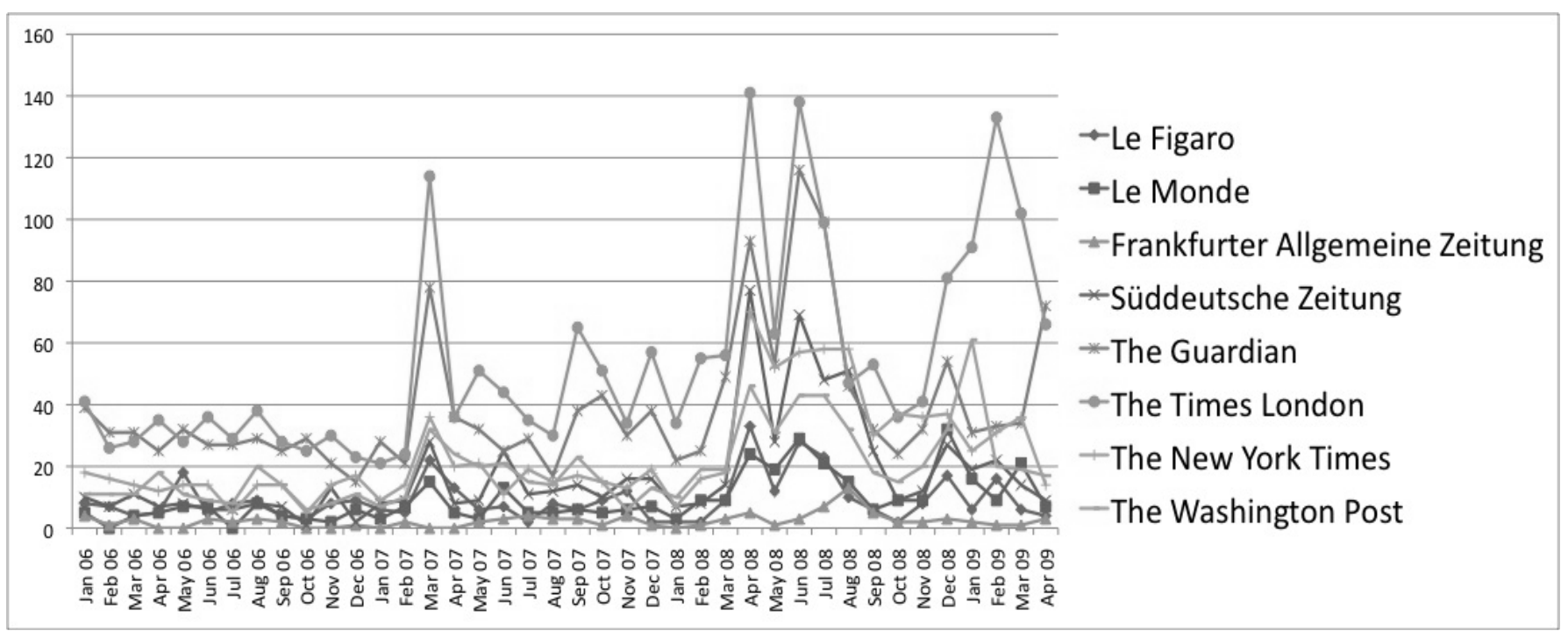

* This frequency graph is based on an analysis of the LexisNexis database (in case of the the Süddeutsche Zeitung and Frankfurter Allgemeine Zeitung on the newspapers' archives) and encompasses all articles, which dealt with Zimbabwe. Please note that the data of April 2009 does not include the articles of 29 and 30 April. We chose leading newspapers (one politically on the center-left and one on the center-right) of the three Western permanent members of the Security Council, France, Great Britain and the US, as well as Germany, which played a crucial role in shaping the European response.

\section{The reluctance of the international commu- nity}

Even if the international reaction to the political tensions and the evolving humanitarian crisis in Zimbabwe were not as rhetorically reluctant as at the regional level, we shall elaborate in the following on the volatility of attention and the half-heartedness of concrete action - except some targeted sanction regimes - characterizing the international, and namely the Western response.

There are various mechanisms and statements from the international actors to protect defenseless populations from systematic state repression - most prominently the 'responsibility to protect', a principle that was enshrined into international law in 2005. This principle - though occasionally rhetorically invoked - has not been the basis for concrete and serious action so far. Both a stalemate in the UN Security Council and the unwillingness to steadily invest political capital and concrete means contributed to that fact; a pattern that can be repeatedly observed e.g. in the case of Zimbabwe. The pressure on the Mugabe regime was never seriously build up once the economic and political situation worsened considerably from 2000 onwards. Instead, the Western governments were all in all responding rather passively and ad-hoc (mostly rhetorically) to the peaks of the crisis being reported in the media. ${ }^{67}$ As can

67 The role of the media in influencing government's behavior when confronted with humanitarian crisis is both theoretically and empirically well established (see, for instance, Entman, Robert (2000): Declarations of Independence - The Growth of Media Power After the Cold War, in: Nacos, B. L., Shapiro, R. Y. and Isernia, P. (Eds.): Decisionmaking in a Glass House: Mass Media, Public Opinion and American and European Foreign Policy in the 21st Century. Rowman \& Littlefield Publishers, London, pp. 11-26.) - however, to assume strong causality, the findings of those studies remain too weak. Nevertheless, there are good reasons to assume a link between those two. For an overview, see: Junk, Julian L. and Joachim Blatter (2007): Peace Entrepreneurs and International Intervention - Navigating Between Negotiation Arenas and Discursive Fields: the Case of Sudan. Millennium Annual Conference, 20-21 October 2007, London. be seen in figure 1, there are on the one hand, a high volatility in media reporting on Zimbabwe and, on the other hand, stark differences between the newspapers of various countries.

The peaks in reporting corresponded with the March 2007 violent protests of the MDC supporters, when Mugabe announced that he would run for re-election in 2008 and in which the opposition leader Tsvangirai got seriously injured ${ }^{68}$, in March/ April 2008 and June 2008 with the election rounds, and in February and March 2009 with the formation of the Unity Government. The general trend holds that steady reporting on the cruel developments from 2006 on was lacking and, as we shall see, this was corresponding partly with a rather passive and half-hearted policy response of the international community.

Media coverage of Zimbabwe varies from state to state. Leading newspapers from Great Britain reported considerably more often on Zimbabwe as did newspapers of France, whereas the United States' press takes a middle ground and the picture of the German press is mixed. This rather simple finding corresponds with the actual policies. Britain as former colonial power obviously has still stronger ties with Zimbabwe's various political actors and was, for a long time, the most active player internationally - even though the colonial past provides Britain with a unique knowledge and unique ties to Zimbabwe, the Mugabe regime defined itself to a large degree on its struggle against foreign domination: Britain was thus an easy target to delegitimze. In particular, Britain was working through the Commonwealth on all issues related to Zimbabwe but it soon had to learn that this institution was blocked by its other African members on this issue. ${ }^{69}$ However, after the inauguration of the Labour-led

68 In March 2007, there is some reporting on the Cricket World Championship too, which led to some articles on the Zimbabwean team, but this does not change the overall trend in reporting.

69 Taylor, Ian and Paul Wiliams (2002): The Limits of Engagement: British Foreign Policy and the Crisis in Zimbabwe, in: International Affairs, 78 /3), pp. 547-656 - here p. 553. 
government under Tony Blair from 1997 onwards, this policy was abandoned gradually and within the "ideological corridor of New Labour", it was promoting an approach that put good governance, human rights and neo-liberal economic policy at its center in various multilateral fora and, over time, more and more bilaterally. ${ }^{70}$ This was evident when, in the years to the run-up of the 2002 presidential elections in Zimbabwe, the overall situation worsened considerably (similarly to the situation in 2008), with a dwindling economy, a rivalry between Mugabe and Tsvangirai and the confiscation of land. Blair's government came under considerable pressure from the public, particularly from the Daily Mail which was reporting widely on the white farmer's problems in Zimbabwe, and finally took an active stance imposing sanction regimes and supporting a EU observer mission ${ }^{71}$. This policy, however, failed. According to Hill, "it was in Zimbabwe that the limits of British influence were most sharply exposed [...] ultimately, Britain was shown as having responsibility but not power". ${ }^{72}$ The Blair government increased the sharpness of its rhetoric afterwards considerably, but being much more reluctant to work multilaterally for Zimbabwe ${ }^{73}$ - some critically dubbed this a "megaphone policy"74. When, for instance, Mugabe sent a letter to the new government in London demanding funds for the land reform program as agreed to in the Lancaster House Agreement of 1979, the response he received from Claire Short, then Secretary of State for International Development, was by all measure undiplomatic ${ }^{75}$ and marks the end of the good relationship with Britain, as a former deputy Ambassador of Zimbabwe to Britain recalls. The letter opened the way for a more confrontational stance against the Mugabe regime in the years to come, when in December 2007, Brown, Blair's successor as Prime Minister, chose not to attend an EU-Africa summit in Lisbon. ${ }^{76} \mathrm{He}$ and his ministers used strong language to explain this decision, while even risking to split the EU. In addition, one should mention the voiceful and heavily politicized Zimbabwean Diaspora in Britain trying to exert influence on the British foreign policy towards Zimbabwe. ${ }^{77}$ Furthermore, Britain was the only country debating publicly and governmentally a military intervention - perhaps as part of carrots and stick strategy: two contingency

70 Ibid. p. 552.

71 This EU observer mission was headed by Peter Schori who was expelled ahead of the 2002 elections by the government of Zimbabwe. BBC News, 18 February 2002, , EU agrees Zimbabwe sanctions” (http://news.bbc.co.uk/2/hi/africa/1827827.stm).

72 Hill, Christopher (2001): Foreign Policy, in: Seldon, Anthony (ed.): The Blair Effect. Little Brown, London, p. 347. Quoted in Taylor/ Williams (2002), p. 547.

73 Until then, the Commonwealth institutions were still an important part of the British policy towards Zimbabwe. After long discussions, Zimbabwe was finally suspended in 2002. In 2003, Mbeki was outvoted when the Commonwealth refused to lift the suspension - Zimbabwe withdrew from this institution. Dowden, Richard (2006): Engaging with Mugabe. The Round Table: The Commonwealth Journal of International Affairs, 95 (384), pp. 283-286, here p. 285 .

74 Williams, Paul D. (2005): Blair's Commission for Africa: Problems and Prospects for UK policy, in: The Political Quarterly, pp. 529-539 - here p. 532.

75 The letter can be found at the following URL: http://maravi.blogspot. com/2007/03/zimbabwe-claire-shorts-letter-nov-5th.html (accessed 03 May 2009).

76 A British threat of boycott had already led to the cancellation of the $2003 \mathrm{EU}$ Africa summit.

77 McGregor, Joann (2009): Associational Links with Home Among Zimbabweans in the UK: Reflections on Long-Distance Nationalisms, in: Global Networks - A Journal of Transnational Affairs, 9 (2), pp. 185-208. plans were leaked and discussed by the ministry of defense, one involving the deployment of troops. ${ }^{78}$

The French approach to Zimbabwe, by contrast, was very cautious. The reason is arguably that the French government focuses on its former colonies in west and central Africa. France acted mainly through its permanent seat in the UN Security Council. While being rather reluctant to position itself publicly, the situation changed considerable in 2008 culminating in July 2008 when it opted clearly for "a reversible sanctions regime and also called for an arms embargo" on Zimbabwe. Thus, the French representative at the UN supported a resolution, which was discussed before the Council on 11 July 2008. After the resolution was not passed due to the veto of Russia and China, ${ }^{79}$ French Ambassador Ripert said that this was a defeat for the UN but it is still "important to ensure the victory of democracy in Zimbabwe." 80

The US position and behavior is quite similar to that of France, even though it appears to be a more active player when it comes to the statement of the G8 on July 8, $2008^{81}$ and its Ambassador Khalilzad, who used more direct language criticizing Russia's and South Africa's performance, warning Zimbabwe's "horrible regime" and pointing to regional instability in Southern Africa. ${ }^{82}$ And in 2001, the US was at the forefront - alongside Britain, as mentioned above - to impose a sanction regime on Mugabe: Being structurally a very important player in shaping and even conducting US foreign policy, the Senate passed the Zimbabwe Democracy and Economic Recovery Act, which forced US officials in International Financial Institutions and multilateral development banks to oppose and vote against loans and guarantees to the government of Zimbabwe. Afterwards however, the US-American policy did not live up to its rhetoric and that act.

The German chancellor Merkel was similarly rigorous in her opening speech at the EU-Africa summit in Lisbon in 2007. She criticized the Zimbabwean government and addressed Mugabe directly. ${ }^{83}$ Merkel's speech prompted harsh reactions from most African leaders present (among them Mbeki) and from the Zimbabwean government. The official German position towards Zimbabwe and the government of Robert Mugabe has been very critical ever since the seemingly manipulated elections in 2002. Several declarations of the German EU Presidency in 2007 (dated 12, 14. and 18 March) criticized the Human Rights

78 The Times, 16 June 2008, „Paddy Ashdown: Military Intervention Could Be Justified“, and „MoD Contingency Plans For Military Action in Zimbabwe“.

79 The resolution called for an arms embargo, and financial and travel restrictions on Mugabe and 13 other regime leaders. The result of the Council's vote was nine in favour (Belgium, Burkina Faso, Costa Rica, Croatia, France, Italy, Panama, United Kingdom, United States), to five against (China, Libya, Russian Federation, South Africa, Viet Nam), with Indonesia abstaining.

80 Department of Public Information, News and Media Division, United Nations, http://www.un.org/News/Press/docs/2008/sc9396.doc.htm (accessed 30 March 2009).

81 See for documents on the official US position on Zimbabwe: http:// www.state.gov/p/af/ci/zi/prs/2009/ and http://southafrica.usembassy. gov/spot-zimbabwe.html (both accessed on 27 March 2009). As for the G8 statement: http://www america gov/st/texttrans-english/2008/July/ 20080708152411bpuh2.582949e-02.html\#ixzz 0DzBD Y7DC\&B (accessed 25 March 2009).

82 http://www.america.gov/st/democracy-english/2008/July/ 20080714145807esnamfuak0.1835901.html\#ixzzODzBaTdNY\&B (accessed 25 March 2009).

83 http://www.eu2007.pt/NR/rdonlyres/7DD5EDD3-E109-47EF-A5C869572208F21B/0/2007120aAlemanhaEUAfrikaGipfel.pdf (accessed $24 \mathrm{March}$ 2009). 
situation in the country and violent actions against opposition movements.

However, in all four cases (France, Germany, Britain and the US), the policy response remained rather rhetorical between 2002 and mid-2008, when most of the Western governments condemned the steps Mugabe took in connection to the second round of elections. In the end, they did not recognize his presidency after the elections and froze all bilateral aid. On the smaller scale, the pressure exerted by media and politics led some Western enterprises to end their business with the Mugabe regime. For instance, the German company Giesecke \& Devrient, specialized in printing treasury notes, finally stopped the shipment of a special paper for those notes to Zimbabwe with the consequence that Reserve Bank Governor Gono faced difficulties to print money that the ZANU-PF regime needed for paying the militias and keeping the large patronage system alive. In general, most of the Western countries established a targeted sanction regime against the ruling elite in Zimbabwe. ${ }^{84}$ But while a quite concerted and active response was observable in the run-up to the 2002 presidential election in Zimbabwe, this policy remained more or less in place, being hardly used as basis to steadily increase the pressure on Mugabe. Comprehensive sanction regimes or even the threat of military intervention were never discussed seriously - apart from in Britain, as seen - with the Security Council blocked and some countries legitimately pondering humanitarian costs.

Alongside South Africa, its "no" to any Security Council action $^{85}$ and its lobbying for lifting sanctions against Zimbabwe ${ }^{86}$, China and Russia used their veto to block any resolution. They argued that sanctions would undermine the mediation efforts of the AU and the SADC and endanger the allegedly democratic process between the Zimbabwean government and the opposition. It also said that the Zimbabwean issue arises from an internal dispute and therefore does not fit into the competencies of the Security Council, which - as authorized by the UN Charter should deal with threats to regional or international peace and security. ${ }^{87}$ China went even one step further by trying, albeit unsuccessfully (at least in one publicly covered instance) to ship weapons to Zimbabwe during the period of the elections, repression and violence - without being confronted with rigorous international diplomatic efforts to block this shipment. ${ }^{88}$

84 In particular, the sanction regime was established by the EU. It was not targeted against Zimbabwe in general but rather included the freezing of personal assets of and imposing travel bans on high ranking officials and senior members of government. In addition it called for a suspension and re-orientation of certain financial and development programs while continuing the humanitarian assistance (cf., for instance, www.delzwe.ec.europa.eu/en/ eu_and_country/EU\%20SANCTION\%20POSITION.pdf). The US coordinated with that sanction regime. Mugabe began lobbying hard against this sanction regime recently - a sign that it has some impact. The upcoming Swedish EU presidency is expected to be willing for a dialogue on this matter.

85 South Africa was non-permanent member of the UN Security Council at this stage.

86 The Guardian, 20 March 2009, "West Must Drop Its Sanctions to Save Zimbabwe, Says Minister".

87 BBC News, 12 July 2008, http://news.bbc.co.uk/2/hi/africa/7502965.stm and The Guardian, 11 July 2008, http://www.guardian.co.uk/world/2008/jul/11/ unitednations.zimbabwe (accessed 30 March 2009).

88 Spiegel, Samuel J. and Philippe LeBillon (2009): China's Weapons Trade: from Ships of Shame to the Ethics of Global Resistance, in: International Affairs, 85 (2), pp. 323-346. Interestingly, it were South African dock workers who refused to let the ship land their goods in Port Elizabeth - underlining the domestically weak position of Mbeki's „quiet diplomacy“ approach. Africa Research Bulletin Vol. 45 No. 4, April 1st-30th, p. 17486 B,C.
In addition, with the blockade of the Security Council, persecution or indictment by the International Criminal Court (ICC) of Mugabe and others responsible for atrocities is not possible. This is due to the fact that Zimbabwe never ratified the statute of the ICC. Hence a resolution of the Security Council is needed.

In sum, the international picture is mixed. Whereas the Western response was driven by a logic of ad hoc involvement without seeking the long-term strategic view and steadily building up pressure on the Mugabe regime, China and Russia alongside South Africa were blocking any attempt in the Security Council to authorize concrete measures that would have serious influence on the ruling elite in Zimbabwe. However, the Western countries established targeted sanction regimes but only occasionally increased the pressure and, all in all, the unambiguous rhetoric of some governments - most importantly the British - were not lived up to. All in all, the international response was at best half-hearted - the key was held by the regional players.

\section{Conclusion and scenarios}

Building upon the described status quo, we aim at providing an outlook for the country's political situation. We develop five different scenarios, concluding that the status quo scenario remains the most likely. Since we consider Mugabe as crucial figure in approaching the political arena of Zimbabwe, the focus of our analysis is on him. We assume that ZANU-PF relies on his power. The question of succession is not solved yet, which contributes to Mugabe's relative strong standing in the ZANUPF ranks. It is important to stress that we are not assuming that the political stalemate in Zimbabwe can be solved merely by Mugabe stepping down. In fact, the situation is far more complex, making it difficult to investigate. As a matter of simplicity, we approach this situation from an angle which places Mugabe at the center.

Four scenarios would threaten Mugabe and his party's grip on power. The first is an international intervention either by the UN, the AU or SADC. As shown, all of these institutions are blocked by structural veto players in the case of Zimbabwe. This renders highly unlikely an international intervention that is legitimized through an international or regional organization. The UN is not intervening because China is backing Mugabe, the $\mathrm{AU}$ is not intervening because Mugabe is respected among many African heads of state and government ${ }^{89}$, and SADC is also not intervening for a variety of reasons, not at least for Mugabe's good standing in this regional body. Angola's President José Eduardo dos Santos for example proved to be as close as Mugabe's other ally Swaziland's King Mswati III. More importantly, however, there are no clear and public signs coming from South Africa. As the regional hegemon, its actions are most crucial. We expect South Africa under Zuma to remain committed to its 'quiet-diplomacy' approach. As a non-permanent member of the UN Security Council, South Africa was at the forefront of those demanding to stay out of Zimbabwe. Britain and the USA are not likely to intervene either, as shown. However un-

89 New York Times, 27 June 2008. 
likely a military intervention might be, it would have been even rhetorically a forceful supplement of a steady carrots and stick approach by the international community. Unfortunately, it was volatility rather then steadiness that has characterized the international response to the Zimbabwean crisis and there are no signs that this might change in the near future.

The second impending scenario is massive pressure from the $\mathrm{AU}$ and SADC. Mugabe was criticized in the closed session of the AU Sharm El Sheikh summit, but managed to silence his critics. ${ }^{90}$ The AU plays only a minor role in the conflict; rather SADC with its appointed mediator Mbeki indeed had a tremendous impact on the country: it was making sure that the MDC could campaign under relatively democratic conditions at the presidential and parliamentary elections in March 2008. The situation changed during the campaigning for the run-off. Mugabe made clear that "no country in the world, including those in the African Union and SADC, can dictate how Zim[babwe] should conduct its elections." 91 Only during August and September 2009, Mbeki as SADC's mediator managed to calm the situation and bring Mugabe to the negotiation table. Mbeki became crucial in facilitating the power-sharing agreement. Notwithstanding, one fact seemed to be sacrosanct for the SADC heads of state and government all the time: Mugabe would not be forced to step down. As they pointed out so often, the solution lies in a power-sharing agreement and not in the resignation of Mugabe. In short, Mugabe personally faces no severe threat from the AU or SADC.

The third scenario is a domestic uprising. Zimbabwe's population has suffered under the ZANU-PF regime for almost 30 years by now and there was never any sign of a massive civil turmoil - and so is the situation now. A successful upraising would require a high degree of organization and a leader who is so charismatic that he or she is followed by the mass. There is neither a platform for an uprising nor is there a trusted leader in sight. Furthermore, the country is still under tight control of the police and armed forces as well as the secret police. Their massive presence in the country makes this scenario even less likely. The way ZANU-PF and the security organs operated in the aftermath of the March 2008 election underscores the argument.

The most threatening scenario for Mugabe is opposition from within his own party, ZANU-PF. There have been attempted coups against him in the past. The Tsholotsho incidence is a case in point. Six out of ten ZANU-PF provincial chairpersons met at a place called Tsholotsho in November 2004 to plan the composition of ZANU-PF's leadership. ${ }^{92}$ Mugabe became alarmed of the 'conspiracy' 93 and suspended the six chairmen from the ZANU-PF. His maneuver makes clear how serious this incident was. Jonathan Moyo, Information Minister at this stage, is thought to have been behind the organization of the meeting. ${ }^{94}$ Moreover, observers assume that Emmerson Mnangagwa joined Moyo in organizing the conspiracy. Surprisingly,

90 Participants of the closed session coming from Cameroon, Egypt, Mauritius, South Africa and Uganda unison stated this during the interviews. 91 Robert Mugabe cited in The Herald, 27 June 2009, p.1

92 Africa Confidential (2004):, 'Zimbabwe: Bye-bye Moyo', Vol. 45 (24), p. 8. 93 Africa Confidential (2004): 'Zimbabwe: A Heartbet away', Vol 45 (25), p.1. 94 Africa Confidential (2004): 'Zimbabwe: Bye-bye Moyo', Vol. 45 (24), p. 8.
Mnangagwa managed to move up in the ZANU-PF hierarchy again, winning Mugabe's favor. He is now again in the JOC. The reason for this is that Mugabe needs all his patrons as much as they need him, particularly a crucial figure like Mnangagwa. There is a mutual dependency. Mugabe is ZANU-PF. The party has no other face. ${ }^{95}$ If Mugabe steps down ZANU-PF faces immense difficulties to secure enough votes to continue ruling - even if the election campaign and the ballot counting were heavily manipulated. ZANU-PF is organized strictly hierarchically under him.

This gives rise to the fact that the last scenario is the most likely - namely that all in all the status quo prevails for the time being. Tsvangirai failed to show credibility ${ }^{96}$ and strength in leading the country and channeling the majority's will into concrete policies. He made unrealistic promises, given the current economic and budgetary situation, e.g. that all teachers will be paid in foreign currency. ${ }^{97}$ Moreover, he has not yet managed to obtain all that Mugabe promised in the power-sharing agreement. His ultimatum from 21 April 2009 directed at Mugabe ${ }^{98}$, will not resonate in any serious policy changes on behalf of ZANU-PF since the Roy Bennett case and the distribution of minister posts proved that Tsvangirai is committed to the power-sharing agreement under almost any circumstances. Additionally, it must not be forgotten that Tsvangirai had to suffer on a very personal level when his wife died in a car accident in March 2009 - given that he is still committed to the agreement, this might render him being even more cautious and mindful in his approach. In short, the MDC is no real threat to Mugabe and his cronies at this stage. ZANU-PF will stay in power and exercise its influence in important policy fields as they did over the past 30 years. Mugabe will be the president with a huge patronage system keeping him in power and his allies satisfied. The "Inclusive Government" will make only a little difference; the international community and the regional organizations are not willing to make a difference. The status quo will remain under the current conditions.

95 Gideon Gono and Emmerson Mnangagwa are waiting prominently in the second line though - see footnote 16

96 Tsvangirai even caused the MDC to split in 2005. A group under the leadership of Arthur Mutambara disagreed with Tsvanigirai's position to participate at the Senate elections of 2005. This split of the MDC weakened the opposition.

97 Mail and Guardian (Johannesburg), 13-19 February 2009, p. 28.

98 Mail and Guardian Online, 22 April 2009, http://www.mg.co.za/article/200904-22-tsvangirai-gives-mugabe-ultimatum (accessed 25 March 2009). 